\title{
Backbone or Backyard of the Convention? The CISG's Final Provisions
}

\author{
Ulrich G Schroeter *
}

\section{INTRODUCTION}

The United Nations Convention on Contracts for the International Sale of Goods (CISG) has become the most successful uniform private law convention in legal history. Proof of this fact is two-fold; on one hand the large number of Contracting States that have ratified the Convention, ${ }^{1}$ and on the other hand - maybe more importantly - the increasing number of cases in which the CISG has been applied by courts and arbitral tribunals. The excellent case collection that Albert Kritzer, in honour of whom this Festschrift submission was written, is tirelessly working on, ${ }^{2}$ bears witness to the Convention's growing importance in legal practice.

The practical application of the CISG has been significantly facilitated by the impressive number of scholarly writings that have been dedicated to various aspects of the Convention. While much has been written about issues addressed in Parts I-III of the Convention (Articles 1-88 CISG), it is striking to note that only little attention has been paid to the Convention's Part IV, entitled 'Final Provisions' (Articles 89-101 CISG). A statement Professor Winship made with respect to international uniform law conventions in general also holds true for the CISG: "No commentator - and I barely exaggerate - spends much time examining the "Final Provisions" of international conventions.' ${ }^{3}$ The primary reason for this apparent neglect seems

\footnotetext{
* Dr iur (Freie Universität Berlin); Akademischer Rat, Albert-Ludwigs-Universität Freiburg.

1 At the time of writing, the CISG had 70 Contracting States. More are expected to follow.

2 Available at: http://cisgw3.law.pace.edu.

3 Winship, P (1990) 'Final Provisions of UNCITRAL's International Commercial Law Conventions' (24) International Lawyer 711.
} 
to lie in the assumption that the CISG's Final Provisions exclusively address questions of public international law, and are therefore of little (if any) interest to international merchants, legal practitioners, courts and arbitrators. Articles 89-101 CISG, so it is said, are addressed to the States in their treatymaking capacity, ${ }^{4}$ and many of the matters they concern are to be handled by government officers, rather than sellers and buyers. ${ }^{5}$ From the perspective of parties engaging in international sales contracts, Part IV of the CISG might therefore be viewed as the 'backyard' of the Convention.

While it is true that the CISG's Final Provisions are also dealing with technical issues raised by the Convention's ratification as well as the related question which rights and obligations arise from the Convention for the respective Contracting State, ${ }^{6}$ it would be incorrect to assume that these issues exclusively belong to the realm of 'public international law' and are therefore of no concern for the CISG's practical application. A Contracting State's obligations arising from the CISG and the Convention's application through the courts of said Contracting State are, in fact, two sides of the same coin. Professor Honnold has described this as 'the commitment that Contracting States make to each other: We will apply these uniform rules in place of our own domestic law on the assumption that you will do the same.' 7

The CISG's Final Provisions may accordingly have a significant influence on the Convention's applicability to a given sales contract, and will often need to be taken into account by commercial lawyers when dealing with the CISG. Their location in the concluding part of the Convention should therefore not distract from the fact that many of the provisions in Part IV address matters which are also regulated elsewhere in the Convention: From a functional perspective, Articles 92-97, 100, 101 CISG belong to Part I, while Articles 92, 96, 100, 101 CISG in addition belong to Parts II and III. The

4 Winship 'Final Provisions' supra fn 3 at 713.

5 Cf Honnold, JO (1999) Uniform Law for International Sales under the 1980 United Nations Convention (3rd ed) Kluwer at para 458.

6 See Schlechtriem, P (1986) Uniform Sales Law - The UN-Convention on Contracts for the International Sale of Goods Manz at p 22: 'Part IV (Articles 89-101) contains in the Final Provisions the obligations of the Contracting States.'

7 Honnold Uniform Law supra fn 5 at para 103.2. The application of the CISG does, one might add, not always have a public international law 'side' to it: the latter is missing whenever a CISG case is decided by either a court in a Non-Contracting State, or an arbitral tribunal. 
close connection that exists between Part IV and the other parts of the CISG becomes particularly obvious when looking at Articles 12 and 96 CISG: These two provisions deal with exactly the same question in exactly the same way, but have (for no apparent reason ${ }^{8}$ ) been placed into two separate parts of the Convention. ${ }^{9}$ When discussing 'Final Provisions', it is therefore always necessary to look at the subject matter of each individual provision, and not merely at their location in Part IV of the CISG.

This article provides an overview of the most important questions that Articles 89-101 CISG have raised, and in particular focuses on those issues that have been discussed by case law. ${ }^{10}$

\section{INTERPRETATION OF ARTICLES 89-101 CISG}

In order to be able to deal with pertinent issues involving the Convention's 'Final Provisions', it it is first necessary to determine which rules govern the interpretation of Articles 89-101 CISG.

\section{Provisions Governing the Interpretation}

In this respect, a number of different approaches have been advocated: While the majority of authors point to the public international law character of Part IV and argue that the applicable rules of interpretation are exclusively those provided for in Articles 31-33 of the Vienna Convention on the Law of Trea-

8 For a discussion of the drafting history see Schroeter, UG (2005) UN-Kaufrecht und Europäisches Gemeinschaftsrecht - Verhältnis und Wechselwirkungen Sellier European Law Publishers at $\S 8$ para 27.

9 Article 12 CISG is, strictly speaking, superfluous; see Herber, R and Czerwenka, B (1991) Internationales Kaufrecht C.H. Beck at Art 12 para 5; Schroeter UN-Kaufrecht und Europäisches Gemeinschaftsrecht supra fn 8 at $\S 8$ para 27; but see Enderlein, F and Maskow, D (1992) International Sales Law Oceana at Art 12 no. 2.1.

10 Note that the UNCITRAL Digest of case law on the United Nations Convention on the International Sales of Goods (published in 2004) does not cover the provisions in Part IV of the Convention. I have attempted to fill this gap by reviewing all relevant cases and arbitral awards listed in the Pace database (http://cisgw3.law.pace.edu): From a public international law perspective, Al's collection of case law on the CISG is reporting on decades of treaty practice. 
ties of 23 May 1969 (thereby excluding the application of Article 7(1) CISG to Articles 89-101 CISG), ${ }^{11}$ others allow for a parallel application of Articles 31-33 Convention on the Law of Treaties and Article 7(1) CISG. ${ }^{12}$ It is submitted that the latter approach should be followed, as Article 7(1) CISG explicitly demands that '[i]n the interpretation of this Convention regard is to be had to its international character and to the need to promote uniformity in its application and the observance of good faith in international trade': ${ }^{13}$ By using the term 'this Convention', Article 7(1) CISG refers to the Convention in its entirety (including its Part IV), as can be deduced from the terminology employed elsewhere in the CISG - whenever a CISG provision merely refers to a specific Part or individual article of the Convention, it specifically says so. ${ }^{14}$ Accordingly, Article 7(1) CISG governs the interpretation of Articles 89-101 CISG,${ }^{15}$ thus eg allowing recourse to these provisions' legislative history in situations in which the more narrowly drafted rule in Article 32 Vienna Convention on the Law of Treaties would prohibit this step. The residuary rules in Articles 31-33 Vienna Convention on the Law of Treaties can, on the contrary, only be applied as far as their content is compatible with Article 7(1) CISG. ${ }^{16}$

11 Enderlein and Maskow International Sales Law supra fn 9 at Art 7 no 2.2; Happ, R (1997) 'Anwendbarkeit völkerrechtlicher Auslegungsmethoden auf das UN-Kaufrecht' Recht der Internationalen Wirtschaft 376 at 377-378; Reinhart, G (1991) UNKaufrecht C.F. Müller at Art 7 para 8; Witz, W in Witz, W, Salger, H-C and Lorenz, M (2000) International Einheitliches Kaufrecht Recht und Wirtschaft at Art 7 para 6.

12 Piltz, B (1993) Internationales Kaufrecht C.H. Beck at 66.

13 Emphasis added.

14 See Article 12 CISG ('Any provision of article 11, article 29 or Part II of this Convention...'), Article 24 CISG ('For the purposes of this Part of the Convention'), Article 27 CISG (' $\ldots$ in this Part of the Convention,...'), Article 92(1), (2) CISG ('... Part II of this Convention or [...] Part III of this Convention'), Article 96 CISG ('... any provision of article 11, article 29 or Part II of this Convention...') and Article 101(1) CISG ('...this Convention, or Part II or Part III of the Convention...').

15 Schroeter, UG (2004) 'The Status of Hong Kong and Macao under the United Nations Convention on Contracts for the International Sale of Goods' (16) Pace International Law Review 307 at 323, available at: http://www.schroeter.li/pdf/ Schroeter_16_Pace_Intl_L_Rev_2004_307.pdf; Schroeter UN-Kaufrecht und Europäisches Gemeinschaftsrecht supra fn 8 at $\S 8$ para 31.

${ }_{16}$ Schroeter UN-Kaufrecht und Europäisches Gemeinschaftsrecht supra fn 8 at $\S 8$ para 32. 


\section{Language Versions of the Convention}

A special question that may arise in the course of interpreting Part IV of the CISG is which language version of the provision should be looked to. Although often discussed in connection with Article 7(1) CISG, this issue is specifically addressed in the so-called 'Witness Clause' which concludes the Final Clauses of the CISG and specifies that (only) the Convention's texts in the six official languages of the United Nations - Arabic, Chinese, English, French, Russian and Spanish - are 'equally authentic'.

This clause, which conforms to common treaty practice, should however not be taken at face value, because not all of the authentic language versions represent the decisions made by the Convention's drafters in equal measure: the English language was the one primarily used during the discussions in Vienna and, maybe more importantly, the only language used by the Diplomatic Conference's drafting committee which produced the final text of the provisions. ${ }^{17}$ The Convention's English text version should therefore, in this author's opinion and based on Article 7(1) CISG, be accorded prevalence where it is in conflict with other language versions, ${ }^{18}$ as the latter are sometimes not more than less-than-accurate translations of the English version. ${ }^{19}$

17 Schlechtriem, P in Schlechtriem, P and Schwenzer, I (eds) (2005) Commentary on the UN Convention on the International Sale of Goods (CISG) (2nd ed) Oxford University Press at Art 7 para 22.

18 See Swiss Supreme Court, 13 November 2003, available at: http://cisgw3.law. pace.edu/cases/031113s 1 .html holding that the English version, and, secondarily, the French version are to be given a higher significance as English and French were the official languages of the Conference and the negotiations were predominantly conducted in English; Brunner, C (2004) UN-Kaufrecht - CISG Stämpfli at 554; Diedrich, F (1996) 'Maintaining Uniformity in International Uniform Law via Autonomous Interpretation: Software Contracts and the CISG' (8) Pace International Law Review 303 at 317-318; Schlechtriem in Schlechtriem \& Schwenzer Commentary supra fn 17 at Art 7 para 22; contra Flechtner, HM (1998) 'The Several Texts of the CISG in a Decentralized System: Observations on Translations, Reservations and other Challenges to the Uniformity Principle in Article 7(1)' (17) Journal of Law and Commerce 187 at 208.

19 On the Spanish text of the CISG, see Barrera Graf, J (1982) 'The Vienna Convention on International Sales Contracts and Mexican Law: A Comparative Study' (1) Arizona Journal of International and Comparative Law 122 at 142. Cf also the general remarks by Aust, A (2000) Modern Treaty Law and Practice Cambridge University Press at 203-204: 'In practice the translations of multilateral treaties are done 
This lack of exactness has also been tacitly acknowledged by the depositary of the Convention (Article 89 CISG), who in recent years has published rectifications of both the authentic Arabic and Russian text versions. ${ }^{20}$

\section{RESERVATIONS}

Among the thirteen articles that make up Part IV of the Convention, the majority lay down one and the same type of final clauses: reservations. According to the definition in Article 2(1)(d) Vienna Convention on the Law of Treaties, a 'reservation' means a unilateral statement, however phrased or named, made by a State, when signing, ratifying, accepting, approving or acceding to a treaty, whereby it purports to exclude or to modify the legal effect of certain provisions of the treaty in their application to that State. The CISG's Final Provisions authorize five reservations ${ }^{21}$ which a Contracting State may declare (multiple reservations are possible ${ }^{22}$ ): Article 92 CISG (entitling States to declare that they will not be bound by Part II or by Part III of the Convention), ${ }^{23}$ Article 93 CISG (the so-called 'federal state clause', allowing certain States to restrict the Convention to only some of their territorial units), Article 94 CISG (authorizing Contracting States that have closely related legal systems to exclude application of the CISG to contracts be-

by translators who, though highly professional, will not have been at the negotiations, and may not necessarily appreciate all the nuances of the final text.'

20 Depositary notifications C.N.862.1998.TREATIES-5 of 19February 1999 (procèsverbal of rectification of the authentic Arabic text), C.N.233.2000.TREATIES-2 of 27 April 2000 (rectification of the Russian authentic text) and C.N.1075.2000.TREATIES-5 of 1 December 2000 (rectification of the original of the Convention [Arabic authentic text]).

${ }^{21}$ This is at least the count favored by most commentators; see eg Flechtner 'The Several Texts of the CISG' supra fn 18 at 193; Torsello, M (2000) 'Reservations to international uniform commercial law Conventions' Uniform Law Review 85 at 91. Others have pointed out that the declaration authorized by Article 93 CISG does not constitute a reservation stricto sensu, cf Aust Modern Treaty Law supra fn 19 at $\mathrm{p}$ $170-171$.

${ }^{22}$ But see Torsello 'Reservations' supra fn 21 at 116 (with a hardly convincing reasoning).

23 Lookofsky, J (2000) 'The 1980 United Nations Convention on Contracts for the International Sale of Goods' in Blanpain, R (ed) International Encyclopaedia of Laws - Contracts Kluwer at para 328: 'surely the most far-reaching reservation permitted'. 
tween enterprises situated in these States), Article 95 CISG (entitling States to declare that they will not be bound by Article 1(1)(b) CISG) and finally Article 96 CISG (authorizing States to exclude the application of the Convention's provisions on freedom of form), with eleven reserving States the Convention's most popular reservation. ${ }^{24}$ Technical questions surrounding the making of declarations under the Convention are governed by Article 97 CISG, and Article 98 CISG clarifies that no reservations are permitted except those expressly authorized in the Convention.

The fact that the Convention allows for reservations at all has often been criticized for allegedly having both decreased uniformity and increased the likelihood of confusion regarding the application of the CISG. ${ }^{25}$ What is certainly true is that it is not always easy to determine the precise effect that a given reservation has on the Convention's practical application. The main difficulty results from the necessity to 'translate' a declaration under public international law - the reservation - into a language familiar to the commercial lawyers and judges entrusted with applying the CISG. As will be demonstrated in more detail below, most problems in this respect can be solved by staying true to the wording of the CISG's Final Provisions. This approach usually leaves no room for calling upon the (residuary!) rules in the Vienna Convention on the Law of Treaties which deal with reservations in general, ${ }^{26}$ as these are being displaced by Articles $92-98$ CISG. $^{27}$

But: Do the Convention's reservations in the past have really lead to non-uniformity and confusion? This question can only be properly answered

24 Argentina, Belarus, Chile, China, Hungary, Latvia, Lithuania, Paraguay, Russian Federation, Ukraine. Estonia's initial reservation has since been withdrawn.

25 Bailey, JE (1999) 'Facing the Truth: Seeing the Convention on Contracts for the International Sale of Goods as an Obstacle to a Uniform Law of International Sales' (32) Cornell International Law Journal 273 at 311; Flechtner 'The Several Texts of the CISG' supra fn 18 at 193: 'reservations have produced substantial nonuniformity'.

26 Cf Bridge, M (1999) The International Sale of Goods: Law and Practice Oxford University Press at para 2.45 .

27 For an approach similar to the one advocated here, see Bridge, M (2005) 'Uniform and Harmonized Sales Law: Choice of Law Issues' in Fawcett, JJ, Harris, JM and Bridge, M International Sale of Goods in the Conflict of Laws Oxford University Press at para 16.122: 'Whatever the impact of the reservations, they must first be interpreted to see how far they are intended to go'. 
by looking at the role that Articles 92-96 CISG have come to play in the Convention's practical application by courts and arbitral tribunals. ${ }^{28}$

\section{Conditions Under Which a Reservation May Be Made under the CISG}

It first should be noted that not all reservations are open for every Contracting State's use: While some of the Convention's reservations can be declared by any State which so desires (Articles 92 and 95 CISG), others provide for certain conditions which need to be satisfied if a Contracting State wants to make use of the reservation (cf Article 19(b) Vienna Convention on the Law of Treaties).

\section{Conditions Laid Down by CISG's Reservations}

\section{ARTICLE 93 CISG}

The 'federal state clause' in Article 93 CISG is only open to a State which 'has two or more territorial units in which, according to its constitution, different systems of law are applicable in relation to the matters dealt with in this Convention' (Article 93(1) CISG). The term 'territorial unit' is flexible enough to include States, cantons, provinces, union republics, ${ }^{29}$ emirates, oversea territories or even Member States. ${ }^{30}$ Commentators have convincingly stressed that Article 93(1) CISG requires that a certain independence

28 The divergence between the (significant) attention that certain reservations have received in scholarly writing and the (limited) importance they have gained in the Convention's practical application is particularly striking when it comes to Article 95 CISG: While this provision has been scrutinized with a truly frightening thoroughness, its practical impact (on Article 1(1)(b) CISG) is diminishing by the day, since Article 1(1)(a) CISG has long become the by far more important basis for the Convention's application. See Bridge The International Sale of Goods supra fn 26 at para 2.45: 'The Article 95 problem is a dying one, the victim of the success of the CISG...'.

29 Herber and Czerwenka Internationales Kaufrecht supra fn 9 at Art 93 para 2.

30 For a potential application of Article 93(1) CISG to Member States of the European Communities see Schroeter UN-Kaufrecht und Europäisches Gemeinschaftsrecht supra fn 8 at $\S 19$ para 32 . 
of the 'territorial unit' is provided for in the State's constitution itself, ${ }^{31}$ while it is insufficient that the power to legislate on certain matters has merely been delegated to a territorial unit. This interpretation is supported by both purpose and legislative history of the provision, which was intended to enable a State to accede to the CISG with respect to individual units, even if it is unable to do so for all of its territorial divisions as it lacks competence over the legal matters governed by the CISG..$^{32}$ The relevant point in time is the moment the declaration is made, not the moment the Convention enters into force for the declaring State. Accordingly, a declaration under Article 93 CISG can also be made if the prerequisites described above have only come into existence after the State had acceded to the Convention, eg because of a change to its constitution or because the State extended its territory by way of an accession of new 'territorial units'. The latter has been the case with the People's Republic of China when Hong Kong and subsequently Macao became part of the PRC as 'Special Administrative Regions'. ${ }^{33}$

\section{ARTicLe 94 CISG}

Article 94(1), (2) CISG restrict the Contracting States which may avail themselves of the reservation to those "which have the same or closely related legal rules on matters governed by this Convention'. While 'the same' legal rules can easily be construed as referring to uniform law in force in the coun-

31 Evans, M in Bianca, CM and Bonell, MJ (eds) (1987) Commentary on the International Sales Law: The 1980 Vienna Sales Convention Guiffrè at Art 93 para 2.1; Schlechtriem in Schlechtriem \& Schwenzer Commentary supra fn 17 at Art 93 para 3; Sono, K (1986) 'Commentary on the Convention on the Limitation Period in the International Sale of Goods, done at New York, 14 June 1974' in UNCITRAL (ed) The United Nations Commission on International Trade Law United Nations at 107: 'an important qualification' (on Article 31(1) of the UNCITRAL Limitation Convention, which served as a model for Article 93 CISG).

32 Schlechtriem in Schlechtriem \& Schwenzer Commentary supra fn 17 at Art 93 para 1.

33 Schroeter 'The Status of Hong Kong and Macao' supra fn 15 at 321-322; see also the discussion infra at $\mathrm{p}$ 462-463. 
tries concerned, ${ }^{34}$ the term 'closely related' remains regrettably vague. ${ }^{35}$ The drafting history of Article 94 CISG provides no particular guidance either, as a variety of potentially covered cases were discussed: The most important one (and, indeed, the reason why the reservation had been developed in the first place) was the Nordic uniform sales law implemented by the Scandinavian States (which later became the only States to make use of Article 94 CISG), but an envisaged uniform sales law between the Benelux countries (which never materialized) and the closely related legal rules in Australia and New Zealand were also mentioned. ${ }^{36}$ In the later academic discussion, Article 94 CISG was thought to be potentially applicable to the relationship between the United Kingdom and Commonwealth countries which still have sales legislation modelled on the English Sale of Goods Act ${ }^{37}$ as well as between Canada and the United States, ${ }^{38}$ but not to the countries belonging to the Romanistic legal family (Italy, France and Spain). ${ }^{39}$

In the end, the line between (merely) related and 'closely' related legal rules remains difficult to draw. Article 94 CISG eventually provides little guidance in this respect. The preferable approach is therefore to accept that it is left to the States contemplating the reservation to decide for themselves

34 It is submitted that uniform law conventions - which are the most important (although not the only) source of uniform law - may prevail over the CISG by way of Article 90 CISG, but may similarly be covered by Article 94 CISG; see Bridge 'Uniform and Harmonized Sales Law' supra fn 27 at para 16.126; Enderlein and Maskow International Sales Law supra fn 9 at Art 94 no 1; Schroeter UN-Kaufrecht und Europäisches Gemeinschaftsrecht supra fn 8 at $\S 10$ para 14.

35 Torsello 'Reservations' supra fn 21 at 95.

36 See Delegates Fokkema (Netherlands) and Bennett (Australia) in (1981) United Nations Conference on Contracts for the International Sale of Goods, Vienna, 10 March-11 April 1980, Official Records, Documents of the Conference and Summary Records of the Plenary Meetings and of the Meetings of the Main Committees United Nations $\mathrm{p} 436$.

37 Winship, P (1983) 'The Scope of the Vienna Convention on International Sales Contracts' in Galston, $\mathrm{N}$ and Smit, H (eds) International Sales: The United Nations Convention on Contracts for the International Sale of Goods Matthew Bender at $\mathrm{p}$ 1-46.

38 Ziegel, J (1982) 'The Vienna International Sales Convention' in Ziegel, J and Graham, W (eds) New Dimensions in International Trade Law: A Canadian Perspective Butterworths 38 at 52 .

39 Torsello 'Reservations' supra fn 21 at 95. 
what is to be considered as 'closely related'. ${ }^{40}$ The vagueness as to this reservation's conditions is somewhat balanced by the requirement of a specific declaration (cf Article 97(2) CISG), albeit not completely: Practically speaking, legal rules are closely related in the sense of Article 94 CISG if and when the reserving States declare them to be.

\section{ARTicLE 96 CISG}

A declaration under Article 96 CISG may only be made by a State which, under its domestic legislation, requires written form for contracts of sale. From the wording of the provision alone it is not entirely clear what kind of domestic form requirements Article 96 CISG refers to: Some commentators argue that Article 96 CISG should not be read as imposing a particular threshold as to the required content and scope of domestic form legislation. ${ }^{41}$ Others convincingly stress that the requirement must basically exist for all contracts of sale and not merely for certain types, and point to the drafting history of the reservation: ${ }^{42}$ A Netherlands proposal to let a limited domestic writing requirement suffice was discussed in detail at the Diplomatic Conference in Vienna, but eventually rejected. ${ }^{43}$

\section{Legal Consequences when Conditions are not (or no longer) Satisfied}

As has been demonstrated, most prerequisites mentioned in Articles 93, 94 and 96 CISG pertain to the content of the domestic law of the reserving State. Reservations, as the Convention which they form part of, have a long life,

40 Brunner UN-Kaufrecht supra fn 18 at Art 94 para 2; Enderlein and Maskow International Sales Law supra fn 9 at Art 94 no 1; Magnus, U in (2005) J. von Staudingers Kommentar zum Bürgerlichen Gesetzbuch: Wiener UN-Kaufrecht (CISG) Sellier-de Gruyter at Art 94 para 5.

41 Enderlein and Maskow International Sales Law supra fn 9 at Art 96 no. 2; Torsello 'Reservations' supra fn 21 at 111.

42 Garro, AM 'The U.N. Sales Convention in the Americas: Recent Developments' (17) Journal of Law and Commerce 219 at 228; Rajski, J in Bianca \& Bonell Commentary supra fn 31 at Art 96 para 3.1; Schlechtriem in Schlechtriem \& Schwenzer Commentary supra fn 17 at Art 96 para 2; Schroeter UN-Kaufrecht und Europäisches Gemeinschaftsrecht supra fn 8 at $\S 6$ para 303 .

43 See Official Records supra fn 36 p 271 et seq. 
and domestic laws may change. This raises the following question: Which legal effect, if any, should a reservation have under the CISG if the requirements for making such a declaration were either not met to begin with or have disappeared at a later stage?

To this end, doubts have in recent years been expressed eg with respect to Denmark's reservation under Article 94 CISG (as Denmark has refused to adopt modifications the other Scandinavian States have implemented into their domestic sales laws, arguably resulting in the Danish law no longer being 'closely related' to the laws of its northern neighbours $)^{44}$ as well as with respect to Argentina's and Chile's reservations under Article 96 CISG (as neither the legislation in Argentina nor Chile prescribes a mandatory written form for all sales contracts) ${ }^{45}$ Similar doubts have frequently been expressed about the Article 96-reservation made by the People's Republic of China, as China's current domestic law no longer requires all international sales contracts to be concluded in writing. ${ }^{46}$

Assuming for the moment that the assessments reported are accurate, what are the consequences for the application of the Convention? While it has been suggested that a reservation must be considered ineffective when its conditions are not satisfied (and should therefore be disregarded by the courts) ${ }^{47}$ the opposing view seems to be correct: Article 97(4) CISG designates the (it is submitted, only) way by which a reservation's effect may be removed, ie through its withdrawal by a formal notification in writing addressed to the depositary. The procedure provided by Article 97(4) CISG thus precludes courts in the various Contracting States from making their own (and possibly divergent) assessments about the compatibility of national

44 Lookofsky, J (1999) 'Alive and Well in Scandinavia: CISG Part II' (18) Journal of Law and Commerce 289 at 290.

45 Garro 'The U.N. Sales Convention in the Americas' supra fn 42 at 229.

46 Wang, X and Andersen, CB (2004) 'The Chinese Declaration against Oral Contracts under the CISG' (8) Vindobona Journal of International Commercial Law and Arbitration 145 at 152; Wu, D (2005) 'CIETAC's Practice on the CISG' Nordic Journal of Commercial Law issue 2005\#2 at 12-13; Yang, F (2006) 'The Application of the CISG in the Current PRC Law and CIETAC Arbitration Practice' Nordic Journal of Commercial Law issue $2006 \# 2$ at 15.

47 Torsello 'Reservations' supra fn 21 at 111 and 117; Wolff, L-C (2008) 'VR China: Neue IPR-Regeln für Verträge' Praxis des Internationalen Privat- und Verfahrensrechts 55 at $57 \mathrm{fn} 38$ (on the Chinese Article 96-reservation). 
laws with Articles 93, 94 and 96 CISG, and thereby avoids a significant legal uncertainty which might otherwise arise. ${ }^{48}$

\section{Time at which a Reservation may be made}

The Convention's reservations can be divided into two groups based on the time at which they may be declared: In accordance with the general rule laid down in Article 19 of the Vienna Convention on the Law of Treaties, three reservations may only be made at the time of signature, ratification, acceptance, approval or accession (Articles 92, 93 and 95 CISG), while the CISG's drafters have generously allowed two others (Articles 94 and 96 CISG) to be made 'at any time'. Within their scope of application, Articles 94 and 96 CISG accordingly provide the Convention with a greater flexibility in dealing with future legal developments on a national or regional level, by leaving room for an increasing regional harmonization in matters of sales law (Article $94 \mathrm{CISG}^{49}$ or for a later introduction of written form requirements into the domestic legislation of Contracting States (Article 96 CISG). ${ }^{50}$ This arguably is a very useful feature, as it allows the Convention - which has occasionally been criticized as resulting in a 'petrification' of the law of sales - to adopt to changing circumstances.

\section{Legal Effects of Reservations made}

Effect as to Subject Matter: Which of the Convention's Rules are Modified?

\section{ARTICLE 92 CISG}

The effect of an Article 92-reservation is to modify the application of the term 'Contracting State' in both Articles 1(1)(a) and 1(1)(b) CISG: As, according to Article 92(2) CISG, the reserving State 'is not to be considered a

48 See Wang and Andersen 'The Chinese Declaration' supra fn 46 at 163-164; Witz in Witz, Salger \& Lorenz International Einheitliches Kaufrecht supra fn 11 at Art 94 para 5.

49 Schlechtriem in Schlechtriem \& Schwenzer Commentary supra fn 17 at Art 94 para 8; Schroeter UN-Kaufrecht und Europäisches Gemeinschaftsrecht supra fn 8 at $\S 10$ para 30 .

50 Enderlein and Maskow International Sales Law supra fn 9 at Art 96 no. 3. 
Contracting State' within the meaning of Article 1(1) CISG, Article 1(1)(a) CISG cannot lead to the applicability of the CISG's rules where one of the parties to the sales contract has its place of business in the reserving State. ${ }^{51}$ The Convention is furthermore not applicable by virtue of Article 1(1)(b) CISG when the private international law rules of the forum declare the law of the reserving State to be applicable to the contract. It should, however, be noted that the effect which an Article 92-reservation has on Article 1(1) CISG is limited in two respects:

First, the effect only extends to the Part of the CISG covered by the reservation made, ie either Part II (contract conclusion) or Part III (rights and obligations under a sales contract). If the reservation pertains to Part II (as all Article 92-reservations made until now do), it accordingly affects the applicability of Articles 14-24 CISG. But the reservation should, it is submitted, be read as also extending to any 'general principles' underlying Articles 14-24 CISG which, in accordance with Article 7(2) CISG, may be invoked eg where a contractual agreement has been reached without clearly identifiable elements of offer and acceptance..$^{2}$ (A German court, however, has ruled otherwise..$^{53}$ ) In Mitchell Aircraft Spares v. European Aircraft Service, a U.S. District Court was faced with another question relating to the effect of an Article 92-reservation: When the reservation displaces the application of the Convention's rules on contract formation in favour of Illinois law which rec-

51 U.S. District Court [N.D. of Illinois], 27 October 1998 (Mitchell Aircraft Spares v. European Aircraft Service), 23 F. Supp. 2d 915, available at: http://cisgw3.law. pace.edu/cases/981027u1.html. But see Oberlandesgericht Naumburg (Germany), 27 April 1999, available at: http://cisgw3.law.pace.edu/cases/990427g1.html: the Convention was declared applicable to a contract between a Danish seller and a German buyer by virtue of Article 1(1)(a) CISG, and Articles 14-19 CISG were applied in order to determine whether a contract had been concluded - the Danish Article 92 CISG-reservation was accordingly overlooked; Oberlandesgericht Frankfurt (Germany), 4 March 1994, available at: http://cisgw3.law.pace.edu/cases/940304g1. html: Articles 14, 19 CISG were applied to a contract between a German seller and a Swedish buyer by virtue of Article 1(1)(a) CISG - the Swedish Article 92 CISGreservation was overlooked.

52 See Schlechtriem in Schlechtriem \& Schwenzer Commentary supra fn 17 at Intro to Arts 14-24 para 5 .

53 Oberlandesgericht München (Germany), 8 March 1995, Recht der Internationalen Wirtschaft (1996), 854, available at: http://cisgw3.law.pace.edu/cases/950308g1. html; cf Schlechtriem's critique in Schlechtriem \& Schwenzer Commentary supra fn 17 at Intro to Arts 14-24 para 10: 'unclear'. 
ognizes the 'parol evidence rule', should this rule - which generally is inapplicable in CISG cases ${ }^{54}$ - be applied to the contract formation at hand? The court answered in the negative and argued that the issue of parol evidence is addressed in Article 8 CISG, which - forming part of Part I of the CISG - remains unaffected by the declaration under Article $92 \mathrm{CISG} ;{ }^{55}$ a possible, but certainly not the only imaginable result. It is furthermore interesting to note that a State declaring that it will not be bound by Part II will apparently nevertheless be bound by Article 29 CISG (governing modifications of contract), as the latter provision is located in Part III of the CISG. This raises the question if an agreement under Article 29(1) CISG to modify, supplement or terminate a contract of sale will be subject to Articles 14-24 CISG, or if the reservation has to be read as also covering matters of contract modification. The wording of Article 92 CISG militates in favor of the former approach, ${ }^{56}$ as does a comparison with the wording of Article 96 CISG, which explicitly speaks of 'article 29, or Part II of this Convention'.

Second, it has to be kept in mind that an Article 92-reservation does not affect Article 1(1)(b) CISG in situations where the conflict of law rules point to the law of another Contracting State, which has not made a reservation under Article 92 CISG - in these cases, the rules of the Convention have to be applied, ${ }^{57}$ and at least one court in an Article 92 CISG-reserving State has done so. ${ }^{58}$

54 See CISG-AC Opinion no 3, Parol Evidence Rule, Plain Meaning Rule, Contractual Merger Clause and the CISG, 23 October 2004 (Rapporteur: Professor Richard Hyland, Rutgers Law School, Camden, NJ, USA), available at: http://www.cisg.law. pace.edu/cisg/CISG-AC-op3.html.

55 Mitchell Aircraft Spares v. European Aircraft Service supra fn 51 at 920-921.

56 Bergsten, E (2008) 'Amending the Contract: Article 29 CISG' in this book at p 54-55.

57 Brunner UN-Kaufrecht supra fn 18 at Art 92 para 3; Enderlein and Maskow International Sales Law supra fn 9 at Art 92 no. 6; Lookofsky 'Alive and Well' supra fn 44 at 294; Schlechtriem in Schlechtriem \& Schwenzer Commentary supra fn 17 at Art 92 para 3.

58 Østre Landsret (Denmark), 23 April 1998 (Elinette Konfektion Trading ApS v. Elodie S.A.), [1998] Ugeskrift for Retsvoesen 1092, available at: http://cisgw3.law. pace.edu/cases/980423d1.html. 


\section{ARTICLE 95 CISG}

The effect of a reservation under Article 95 CISG is to exclude the reserving State's duty under public international law to apply Article 1(1)(b) CISG. The wording of Article 95 CISG, which - couched in classical public international law terms - entitles any State to declare 'that it will not be bound by subparagraph (1)(b) of Article 1 of this Convention', makes amply clear that the application of Article 1(1)(a) CISG is e contrario not affected by the reservation: Reserving States continue to be bound by this provision. ${ }^{59}$ Apart from this indication, Article 95 CISG provides little guidance to courts and arbitrators when it comes to determining the reservation's exact effect on the Convention's practical application, as it lacks a specific paragraph dealing with this question comparable to the ones that Articles 92-94 CISG have been endowed with. This difference in drafting style can be traced back to Article 95 CISG's legislative history: The reservation was only included into the Convention due to a last-minute decision in the Plenary Conference, ${ }^{60}$ which meant that its wording did not undergo extensive scrutiny in a drafting committee.

It is therefore not entirely surprising that different opinions have been advocated when it comes to the question whether the courts in a reserving State, even when - due to Article 95 CISG - not obliged to do so under public international law, are still entitled to apply the Convention in cases in which the prerequisites of Article 1(1)(a) CISG are not fulfilled. The domestic law of one Article 95 CISG-reserving State - Singapore - contains a specific rule through which the national legislator has explicitly excluded the application of the CISG in all cases in which Article 1(1)(a) is inapplicable. ${ }^{61}$ But also in the United States, an Article 95 CISG reserving State that lacks a specific domestic law dealing with this situation, at least two District Courts

59 U.S. District Court [New Jersey], 15 June 2005 (Valero Marketing v. Greeni), 373 F.Supp.2d 475, 482, available at: http://cisgw3.law.pace.edu/cases/050615u1. html; Schlechtriem in Schlechtriem \& Schwenzer Commentary supra fn 17 at Art 95 para 3.

60 See Official Records supra fn 36 p 229 et seq.

${ }_{61}$ See Sub-section 3(2) of the Singapore Sale of Goods (United Nations Convention) Act: 'Sub-paragraph (1)(b) of Article 1 of the Convention shall not have the force of law in Singapore and accordingly the Convention will apply to contracts of sale of goods only between those parties whose places of business are in different states when the States are Contracting States'. 
have taken the same position and held that the only circumstance in which the CISG can be applied by a U.S. court is if all the parties to the contract are from Contracting States. ${ }^{62}$ It is, however, important to note that there is nothing in Article 95 CISG itself that would prevent a court in a reservation State from applying the CISG in cases in which its private international law (eg by honouring a choice of law clause forming part of the parties' contract) points to a law of a Contracting State: Article 95 CISG in itself merely excludes the reserving State's obligation to do so, but leaves the ensuing question of how to determine the applicable law entirely to the domestic conflict of laws rules. ${ }^{63}$ If these lead to the applicability of the Convention - as they well may $^{64}$ - this result is reached by way of the rules of private international law only, without Article 1(1)(b) CISG being involved. ${ }^{65}$

\section{ARTicLe 96 CISG}

There is disagreement about the precise effect of a reservation under Article 96 CISG, which entitles a Contracting State to "make a declaration [...] that any provision $[\ldots]$ of this Convention, that allows $[\ldots$ an ...] indication of intention to be made in any form other than in writing, does not apply where any party has his place of business in that State'. ${ }^{66}$ One school of thought believes that in every case in which one of the contracting parties

62 U.S. District Court [S.D. Florida], 22 November 2002 (Impuls v. Psion-Teklogix), 234 F.Supp.2d 1267, 1272, available at: http://cisgw3.law.pace.edu/cases/021122u1. html; U.S. District Court [W.D. Washington], 17 July 2006 (Prime Start v. Maher Forest Products), Internationales Handelsrecht (2006), 259 at 260, available at: http://cisgw3.law.pace.edu/cases/060717u1.html.

63 Brunner UN-Kaufrecht supra fn 18 at Art 95 para 1.

${ }^{64}$ Ferrari, F (2006) 'Short notes on the impact of the Article 95 reservation on the occasion of Prime Start Ltd. v. Maher Forest Products Ltd. et al., 17 July 2006 (IHR 2006, 259)' Internationales Handelsrecht 248 at 250.

65 Bell, GF (2005) 'Why Singapore should withdraw its reservation to the United Nations Convention on Contracts for the International Sale of Goods (CISG) ${ }^{`}$ (9) Singapore Year Book of International Law 55 at 65.

${ }_{66}$ See Honnold Uniform Law supra fn 5 at para 129: 'The language of Articles 12 and 96 has led to uncertainty...'. It has to be stressed that the present question turns on an interpretation of Article 96 CISG, rather than on Article 21 Vienna Convention on the Law of Treaties, as the latter provision - if at all applicable - is residuary in nature; but cf Basedow, J (2006) 'Uniform Private Law Conventions and the Law of Treaties' Uniform Law Review 731 at 740-741. 
involved has his place of business in an Article 96 CISG reservation State, the writing requirements embedded in the law of that State apply. ${ }^{67}$ According to this approach, which has been justified with the acceptance by the Convention of the need, felt by some States, for protection against claims unsupported by a written agreement, ${ }^{68}$ Articles 12, 96 CISG would result in the universal applicability of the reserving State's national law on formal requirements, whenever a party from this State is involved. A number of Chinese $^{69}$ and Russian ${ }^{70}$ arbitral tribunals (at least implicitly) seem to have adopted this view, when they naturally applied the writing requirement in

67 Honnold Uniform Law supra fn 5 at para 129; Reinhart UN-Kaufrecht supra fn 11 at Art 12 para 3.

68 Honnold Uniform Law supra fn 5 at para 129.

69 See CIETAC Arbitral Award, 31 December 1997 (Lindane case), available at: http://www.cisg.law.pace.edu/cisg/wais/db/cases2/971231c1.html: 'when ratifying the Convention, China denounced Articles 11 and 29 of the Convention on formation, modification and termination of the contract, that need not to be concluded by means of writing. Therefore, the formation of the contract must be concluded by means of writing'; CIETAC Arbitral Award, 17 October 1996 (Tinplate case), available at: http:/www.cisg.law.pace.edu/cisg/wais/db/cases2/961017c1.html: 'China made a reservation when signing the CISG, requiring written format'; CIETAC Arbitral Award, 6 September 1996 (Engines case), available at: http://www. cisg.law.pace.edu/cisg/wais/db/cases2/960906c1.html; CIETAC Arbitral Award, 29 March 1999 (Flanges case), available at: http://www.cisg.law.pace.edu/cisg/wais/db/ cases2/990329c1.html: Form requirements in the 'Law of the People's Republic of China on Economic Contracts Concerning Foreign Interests' applied to CISG contract between Seller from China and Buyer from the U.S. (the award does not indicate why Chinese law was applied).

${ }_{70}$ Tribunal of International Commercial Arbitration at the Russian Federation Chamber of Commerce and Industry, 9 June 2004, No 125/2003, available at: http:// www.cisg.law.pace.edu/cisg/wais/db/cases2/040609r1.html, para 3.3: 'the Tribunal calls attention to the fact that, if one of the parties to an agreement is a Russian company, according to art. 12 of the Vienna Convention of 1980, alterations of the conditions of the agreement $[\ldots]$ is admissible only in written form and cannot be proved solely by the testimony of witnesses. This provision of the Vienna Convention of 1980 takes into consideration peremptory norms of Russian civil legislation (art. 162 of Russian Civil Code), according to which non-observance of simple written form of an external economic agreement entails its nullity'; Tribunal of International Commercial Arbitration at the Russian Federation Chamber of Commerce and Industry, 16 February 2004, No 107/2002, available at: http://www.cisg.law.pace.edu/cisg/ wais/db/cases2/040216r1.html, para 3.4.1. (But note that, in both awards, the tribunal also declared Russian law to be applicable according to conflict of laws rules.) 
Chinese respectively Russian law to CISG contracts. It has furthermore been confirmed by a Russian court decision. ${ }^{71}$

The correct view, however, seems to be that the Article 96 CISG reservation merely excludes the ipso iure applicability of Article $11 \mathrm{CSG}$ (and other provisions of the Convention affecting formal requirements), but says nothing about the question which law will govern the formal validity of the parties' declarations: This matter is rather left for the private international law rules of the forum to determine. ${ }^{72}$ Only this interpretation is in accordance with both the wording of Articles 12, 96 CISG (which provide that the CISG's freedom of form provisions do 'not apply', rather than entitling a reservation State to declare that his own form requirements do apply) and with the Convention's drafting history, during which the contrary construction was discussed, but explicitly rejected. ${ }^{73}$ Courts from Austria, Belgium, Hungary, the Netherlands and the Russian Federation (among them two Supreme Courts) have taken the approach advocated here. ${ }^{74}$ In practical terms, this means that the principle of freedom of form may still apply in accordance with Article $11 \mathrm{CISG}$ if the applicable conflict of law rules point to the law of a CISG Contracting State which has not made a reservation under Article 96 CISG. ${ }^{75}$ Only if the forum's conflict of laws rules call for the application of

71 Presidium of the Supreme Arbitration Court of the Russian Federation, 25 March 1997, Resolution No 4670/96, available at: http:/cisgw3.law.pace.edu/ cases/970325r1.html: 'Article 12 establishes that a contract of sale shall be made or modified in writing.'

72 District Court Rotterdam (Netherlands), 12 July 2001 (Hispafruit BV v. Amuyen S.A.), available at: http://www.cisg.law.pace.edu/cisg/wais/db/cases2/010712n1.html; Lookofsky 'The 1980 United Nations Convention' supra fn 23 at para 332; Schlechtriem in Schlechtriem \& Schwenzer Commentary supra fn 17 at Art 96 para 3.

73 See Rajski in Bianca \& Bonell Commentary supra fn 31 at Art 96 para 1.2; Schlechtriem in Schlechtriem \& Schwenzer Commentary supra fn 17 at Art 96 para 3.

74 See the following two footnotes.

75 Supreme Court (Netherlands), 7 November 1997 (J.T. Schuermans v. Boomsma Distilleerderij/Wijnkoperij), Nederlands Internationaal Privaatrecht (1998) No 91, available at: http://www.cisg.law.pace.edu/cisg/wais/db/cases2/971107n1.html: Article 11 CISG was first declared inapplicable to a Russian-Dutch contract because of the Russian reservation under Article 96 CISG, but was then applied as part of Dutch law which, being the law at the seller's place of business, was deemed applicable by virtue of the Dutch private international law rules; Supreme Court (Austria), 22 October 2001, available at: http://www.cisg.law.pace.edu/cisg/wais/db/cases2/011022a3. html: despite Hungary's declaration under Art. 96 CISG, a merely implicitly con- 
a reservation State's law, will the formal requirements of that law come into play (and possibly result in the invalidity of oral communications made by the parties). ${ }^{76}$

Effect as to Addressee: Which Countries' Courts have to Observe the Reservation?

\section{Articles 92, 93, 94 CISG}

The drafters of Articles 92 and 93 CISG described the effect of these reservations comparatively clearly by stipulating that a reserving State 'is not to be considered a Contracting State' (Article 92(2) CISG) resp. that a party's place of business 'is considered not to be in a Contracting State, unless it is in a territorial unit to which the Convention extends' (Article 93(3) CISG): The general language used makes clear that this effect has to be observed by courts in any State (and not only reserving States), thus creating an erga omnes effect. ${ }^{77}$ In this author's opinion, the same must hold true for reservations under Article 94 CISG, their effect being that the Convention 'is not to

cluded Austrian-Hungarian contract was held formally valid as the Austrian conflict of law rules pointed to Austrian law; District Court Rotterdam (Netherlands), 12 July 2001 (Hispafruit BV v. Amuyen S.A.) supra fn 72; Metropolitan Court (Hungary), 24 March 1992 (Adamfi Video v. Alkotók Studiósa Kisszövetkezet), available at: http:// www.cisg.law.pace.edu/cisg/wais/db/cases2/920324h1.html: although Hungary has declared a reservation under Article 96 CISG, an oral German-Hungarian contract was held formally valid as the Hungarian conflict of laws rules pointed to German law.

76 Presidium of the Supreme Arbitration Court of the Russian Federation, 20 March 2002, Resolution No 6134/01, available at: http://www.cisg.law.pace.edu/cisg/wais/ db/cases2/020320r1.html: Russian law applied by virtue of the Russian private international law rules - oral modification of contract held invalid; Rechtbank van Koophandel Hasselt (Belgium), 2 May 1995 (Vital Berry Marketing v. Dira-Frost), Rechtskundig Weekblad (1995-96) no 40, available at: http://www.cisg.law.pace.edu/ cisg/wais/db/cases2/950502b1.html: Chilean law applied by virtue of the Belgian private international law rules - oral modification of contract held invalid.

77 U.S. District Court [New Jersey], 15 June 2005 (Valero Marketing v. Greeni) supra fn 59 (on Finland's Article 92-reservation); Bridge 'Uniform and Harmonized Sales Law' supra fn 27 at para 16.123; Torsello 'Reservations' supra fn 21 at 97-98; contra De Ly, F (2005) 'Sources of International Sales Law: An Eclectic Model' (25) Journal of Law and Commerce 1 at 9. 
apply' to contracts of sale or to their formation where the parties have their places of business in reserving States (Article 94(1), (2) CISG). ${ }^{78}$

On a practical level, it is not entirely surprising to see that courts in non-reserving States are generally more likely to ignore a reservation's effect than courts in reserving States: While no cases have been reported in which a court intentionally refused to observe a 'foreign' Article 92, 93 or 94 CISG-reservation, a number of courts have in the past overlooked reservations made by other Contracting States ${ }^{79}$ (despite the fact that these are listed in every list of Contracting States). Much seems therefore to depend on how well the parties are represented during the court proceedings, as a simple reference to the fact that a party has its place of business in a reserving State will often suffice to bring the reservation's effect to bear in a foreign court. ${ }^{80}$

\section{ARTICLE 95 CISG}

The interpretation of Article 95 CISG raises more difficult problems. After the final text of the Convention had been adopted, it soon became obvious that commentators were divided when it came to the question if an Article 95 CISG declaration is of any relevance in courts of a non-reserving State. The ensuing academic discussion, which continues until today, centers around the following question: Which law of sales does the court in a non-Article 95 CISG-reserving State have to apply to a contract of sale, when at least one of the parties to that contract does not have its place of business in a Contracting State (meaning that Article 1(1)(a) CISG cannot apply) and the forum's private international law rules (which the court then has to resort to under Ar-

78 Brunner UN-Kaufrecht supra fn 18 at Art 94 para 4; Magnus Kommentar supra fn 40 at Art 94 para 7; Schlechtriem in Schlechtriem \& Schwenzer Commentary supra fn 17 at Art 94 para 9; for the opposing view see De Ly 'Sources' supra fn 77 at 10; Ferrari, F in Schlechtriem, P and Schwenzer, I (eds) (2004) Kommentar zum Einheitlichen UN-Kaufrecht - CISG - (4th ed) C.H. Beck at Art 94 para 3; Herber and Czerwenka Internationales Kaufrecht supra fn 9 at Art 94 para 8.

79 German Courts of Appeals have acted particularly unfortunate in this respect; see Oberlandesgericht Naumburg, supra fn 51 (Denmark's Article 92 CISG-reservation overlooked); Oberlandesgericht Frankfurt, supra fn 51 (Sweden's Article 92 CISGreservation overlooked).

80 See Valero Marketing v. Greeni supra fn 59 at 480: 'As Valero [U.S.] correctly notes, the CISG doesn't govern in this matter with respect to contract formation...' (on Finland's Article 92-reservation). 
ticle 1(1)(b) CISG) point to the law of an Article 95 CISG-reserving State? A significant number of authors believe that the reference of its conflict rules to the law of a reserving State should lead the court to apply the same sales law as the courts in the reserving State would, ie not the CISG.$^{81}$ The Federal Republic of Germany has supported this approach by way of an interpretative declaration (to be discussed in more detail below) ${ }^{82}$ In doing so, this school of thought declares the Article 95 CISG reservation of a Contracting State to be, at least to a certain extent, binding on other Contracting States.

It is submitted that this interpretation of Article 95 CISG is at odds both with the wording of the provision and with a systematic comparison with Articles 92-94 CISG: By allowing each Contracting State to declare that it will not be bound by Article 1(1)(b) CISG, Article 95 CISG clearly specifies that other Contracting States will continue to be bound by Article 1(1)(b) CISG even when the sales contract at hand involves a party from a reserving State. In striking contrast to Articles 92(2), 93(3) and 94(2) CISG, there is nothing in Article 95 CISG to indicate that the reservation does have any effect on the reserving State's status as a Contracting State under Article 1(1) CISG. ${ }^{83}$

81 Bell 'Why Singapore should withdraw' supra fn 65 at 64; Evans in Bianca \& Bonell Commentary supra fn 31 at Art 95 para 3.4; Kritzer, AH (1989) Guide to Practical Applications of the United Nations Convention on Contracts for the International Sale of Goods Kluwer at 78; Magnus Kommentar supra fn 40 at Art 95 para 6; Schlechtriem in Schlechtriem \& Schwenzer Commentary supra fn 17 at Art 95 para 4: 'normally not the CISG'; Schlechtriem, P (2005) 'Requirements of Application and Sphere of Applicability of the CISG' (36) Victoria University of Wellington Law Review 781 at 784; Ziegel, J (2005) 'The Scope of the Convention: Reaching out to Article One and Beyond' (25) Journal of Law and Commerce 59 at 66.

82 It is interesting to note that in the only German court decision in which such a situation has ever arisen, the Oberlandesgericht Düsseldorf (Germany), 2 June 1993, Recht der Internationalen Wirtschaft (1993), 845, available at: http://cisgw3.law. pace.edu/cases/930702g1.html adopted the opposite approach: The case involved a contract between a seller from Indiana (USA) and a buyer from Germany, with the contract having been concluded at a time when Germany had not yet ratified the CISG (which meant that, according to Article 100 CISG, the Convention could not be applied by virtue of Article 1(1)(a) CISG). The Court of Appeals instead looked to Article 1(1)(b) CISG, ruled that the German rules of private international law lead to the application of the law at the seller's place of business (ie Indiana) and held that the CISG applied.

83 For an author contrasting the wording of Articles 92 and 95 CISG, see Bell 'Why Singapore should withdraw' supra fn 65 at 63-64. 
Article 1(1)(b) CISG, furthermore, explicitly instructs each court that 'This Convention applies [...] when the rules of private international law lead to the application of the law of a Contracting State', ${ }^{84}$ and not that the law of that Contracting State is to be applied. In conclusion, an Article 95 CISG declaration does neither have an 'erga omnes' effect, nor is it to be taken into account by courts in other States when applying Article 1(1)(b) CISG - the relevance of the Article 95 CISG reservation is, in sum, limited exclusively to the reserving State. ${ }^{85}$

\section{ARTICLE 96 CISG}

As the wording of Articles 12, 96 CISG ('any provision [...] does not apply') makes clear, a reservation declared in accordance with these provisions must not only be observed by the courts in the reserving State, but also by courts in other States which themselves might not have declared a similar reservation. ${ }^{86}$ Case law has confirmed this view. ${ }^{87}$

84 Emphasis added.

85 Oberlandesgericht Düsseldorf (Germany), 2 June 1993, supra fn 82; Bridge The International Sale of Goods supra fn 26 at para 2.44; Enderlein and Maskow International Sales Law supra fn 9 at Art 95 no 1; Ferrari in Schlechtriem \& Schwenzer Kommentar supra fn 78 at Art 1 para 78; Ferrari 'Short notes' supra fn 64 at 251; Lando, O (1987) 'The 1985 Hague Convention on the Law Applicable to Sales' (51) Rabels Zeitschrift für ausländisches und internationales Privatrecht 60 at 82; Torsello 'Reservations' supra fn 21 at 108-109.

86 Flechtner 'The Several Texts of the CISG' supra fn 18 at 197; but see Basedow 'Uniform Private Law Conventions' supra fn 66 at 740-741; Bridge 'Uniform and Harmonized Sales Law' supra fn 27 at para 16.140; Torsello 'Reservations' supra fn 21 at 105.

87 Supreme Court (Netherlands), 7 November 1997, supra fn 75: Russian Article 96-reservation observed by Dutch court; District Court Rotterdam (Netherlands), 12 July 2001 (Hispafruit BV v. Amuyen S.A.), supra fn 72: Argentinian Article 96-reservation observed by Dutch court; COMPROMEX (Mexico), 29 April 1996, 17 Journal of Law and Commerce (1998) 427, http://www.cisg.law.pace.edu/cisg/wais/ db/cases2/960429m1.html: Argentinian Article 96-reservation observed by Mexican government commission; Rechtbank van Koophandel Hasselt (Belgium), 2 May 1995, supra fn 76: Chilean Article 96-reservation observed by Belgian court. 
Temporal Scope of Effect: When does the Reservation's Effect Commence and Lapse?

Generally speaking, a reservation under the Convention takes effect either simultaneously with the entry into force of the Convention for the reserving State or, if the reservation is only declared at a later stage (as possible under the 'at any time' wording of Articles 94 and 96 CISG), on the first day of the month following the expiration of six months after the date of its receipt by the depositary (Article 97(3) sentences 1 and 2 CISG). The reservation then remains effective until it is withdrawn in accordance with Article 97(4) CISG. ${ }^{88}$

A more complicated regime applies to reservations made in accordance with Article 94 CISG, as this reservation needs to be declared with respect to one or more other States with whom the reserving State shares 'closely related legal rules'. When both States are Contracting States, the necessary declarations must be either 'jointly' or 'reciprocal' (Article 94(1) CISG), ${ }^{89}$ if only one of the States concerned has ratified the CISG, a declaration by the Contracting State suffices (Article 94(2) CISG). The need for a concertated action that is inherent in Article 94 CISG may result in an unexpected lapse of a reservation's effect, as the example of Iceland demonstrates: When it had not yet ratified the CISG, Iceland had been the subject of Article 94(2)-reservations by Denmark, Finland, Norway or Sweden, with whom Iceland shares a closely related sales law. Upon its accession to the Convention, ${ }^{90}$ Iceland failed to make any declarations in accordance with Article 94(3) CISG (a requirement that probably had been overlooked by the responsible officials), which caused the existing reservations to lose effect and the Convention to surprisingly - apply between Iceland and its Scandinavian neighbour States from 1 June 2002 onwards. Only after Iceland had on 12 March 2003 effect-

88 Since the Convention entered into force, Canada withdrew its Article 95-reservation (with respect to the Canadian province of British Columbia) in 1992, and Estonia its Article 96-reservation in 2004.

89 Article 97(3) sentence 3 CISG specifically regulates when 'reciprocal' declarations take effect.

90 Iceland acceded to the CISG on 10 May 2001, and the Convention took effect for Iceland on 1 June 2002 in accordance with Article 99(2) CISG. 
ed a notification pursuant to Article 94(1) CISG, ${ }^{91}$ the Iceland-Scandinavian trade was again exempt from the territorial scope of the Convention.

Finally, the temporal scope of a reservation's effect may also be affected in cases involving a succession of States. Related questions will be discussed below in the section dealing with the succession of States and territories. ${ }^{92}$

\section{Unclear Reservations (and How to Avoid Them)}

Even when properly construed, any reservation to a uniform law convention by definition reduces the degree of uniformity achieved and may render the convention's practical application more difficult. Article 98 CISG implicitly acknowledges this fact by providing that 'No reservations are permitted except those expressly authorized in this Convention', thereby limiting the States' general 'freedom of contract' under public international law ${ }^{93}$ and, at the same time, trying to reduce the number and content of reservations that courts and arbitrators may have to deal with.

A particular difficulty (and one not directly addressed by Article 98 CISG) arises when a Contracting State makes an unclear reservation.

\section{The Armenian Declaration}

The Convention's more recent history provides the following example. When depositing its instrument of accession to the CISG with the Secretary-General of the United Nations (Article 91(4) CISG) in 2006, Armenia initially filed the following declaration:

'Pursuant to Article 94, paragraph 1 and 2 of the Convention on Contracts for the International Sale of Goods, the Republic of Armenia declares that the Convention shall not apply to contracts of

91 Pursuant to Article 97(3) sentence 3 CISG, this declaration took effect on 1 October 2003.

92 See infra p 463.

93 Treaty clauses introducing limitations of this sort are acknowledged by Article 19(b) Vienna Convention on the Law of Treaties. 
sale where the parties have their places of business in the Republic of Armenia.'

What seems clear from the wording of the declaration is that the Republic of Armenia attempted to formulate a 'reservation' in the sense defined by Article 2(1)(d) Vienna Convention on the Law of Treaties, ie a 'unilateral statement $[\ldots]$ made by a State $[\ldots]$ whereby it purports to exclude or to modify the legal effect of certain provisions of the treaty in their application to that State'. Beyond this, Armenia's declaration neither conformed to the wording of Article 94 (1), (2) CISG nor the general spirit of a reservation allowed under this provision, and its possible meaning remains uncertain. In this particular case, the declaration's lack of clarity remained without practical consequences, as the Republic of Armenia apparently withdrew its declaration of accession before the CISG could enter into force for Armenia. ${ }^{94}$

The risk of making unclear reservations is, however, general in nature, as demonstrated by the fact that the People's Republic of China also made a reservation under the CISG which lacks clarity: ${ }^{55}$ Although the wording of China's declaration resembles an Article 96 CISG reservation, its language is not as encompassing because it only refers to Article 11 CISG, but neither mentions Article 29 CISG nor Part II of the Convention. ${ }^{96}$

94 According to Article 2(1)(g) Vienna Convention on the Law of Treaties, a 'party' to a treaty is a State which has consented to be bound by the treaty and for which the treaty is in force - at that point, and only at that point, is the State bound by the treaty (Aust Modern Treaty Law supra fn 19 at p 75). Commentators convincingly argue that there is no reason why a withdrawal of an instrument of accession which has been deposited with the depositary of a multilateral treaty cannot be done, provided that the withdrawal occurs before the instrument takes effect (see id at p 95-96). According to Article 99(2) CISG, the Convention only enters into force in respect of an acceding State on the first day of the month following the expiration of twelve months after the date of the deposit of its instrument of accession - thus, the withdrawal by Armenia seems to have been effectuated in a timely manner. At the time of writing, the Republic of Armenia is not listed as a Contracting State to the CISG.

95 Declaration made by the People's Republic of China upon approval of the Convention on 11 December 1986.

96 The declaration's wording is (partially) reproduced infra in the next paragraph. 
Against this background, it constitutes a desirable goal to develop procedures designed to avoid potential unclarities. As a starting point, two steps come to mind: First, is seems advisable for the States to keep the content of their reservations to the necessary minimum, and to refrain from repeating the text of reservation provisions from which, according to Article 98 CISG, they are not free to derogate. A reservation reading 'State $\mathrm{X}$ makes a declaration in accordance with Article 96' is thus preferable to 'State X does not consider itself to be bound by Article 11 as well as the provisions in the Convention relating to the content of Article $11^{\prime}:{ }^{97}$ Numbers are, in short, preferable to words. As a second measure, UNCITRAL (or a similar institution) could make model reservations available to the Contracting States, enabling them to use model wordings developed by experts when formulating a reservation under a uniform law convention.

\section{Interpretation of Unclear Reservations by the Courts}

In cases in which an unclear reservation has been made, it will be up to the courts and arbitrators to interpret the respective reservation in order to determine its effect upon the Convention's application to the case at hand. In doing so, it is submitted that Article 31(1) Vienna Convention on the Law of Treaties in conjunction with Article 98 CISG provide an important interpretative guideline: When read together, these two treaty provisions indicate that all reservations should be interpreted in good faith in accordance with the ordinary meaning to be given to the terms used therein and thus, in the light of the object and purpose of Article 98 CISG, should be construed as invoking Articles 92-96 CISG (only) in accordance with the respective reservation's prerequisites and effect as laid down in these Final Provisions.

In accordance with this interpretative guideline, the People's Republic of China's declaration pertaining to form requirements should be read as not only covering Article 11 CISG, but also the Convention's other provisions allowing for an oral or implicit conclusion, modification or termination of

97 Cf the declaration by the People's Republic of China referred to supra. 
CISG contracts, as this reading conforms to the reservation's effect as laid down in Article 96 CISG. ${ }^{98}$

\section{'INTERPRETATIVE DECLARATIONS'}

Occasionally, Contracting States attach to their instruments of accession statements which, on their face, do not purport to 'exclude or modify the legal effect' of the CISG for the State making them (and are therefore not to be regarded as 'reservations' in the sense used by Articles 2(1)(d), 19-21 Vienna Convention on the Law of Treaties), but rather seek to provide an interpretation of certain provisions of the Convention. Declarations of this sort, which are commonly referred to as 'interpretative declarations', ${ }^{99}$ pose particular problems when made under a uniform law convention like the CISG.

\section{Examples of Declarations 'Interpreting' the CISG}

The Hungarian Declaration on Article 90 CISG

When Hungary on 16 June 1983 deposited its instrument of ratification with the depository of the CISG, being among the first States to do so, the instrument contained the following declaration:

'[The Hungarian People's Republic] considers the General Conditions of Delivery of Goods between Organizations of the Member Countries of the Council for Mutual Economic Assistance/GCD CMEA, 1968/1975, version of 1979 / to be subject to the provisions of article 90 of the Convention'.

One can only speculate what prompted the Hungarian Government to make this explanatory statement addressing the (today largely obscure) 'GCD CMEA', a comprehensive set of rules governing the intra-COMECON

98 See also Wang and Andersen 'The Chinese Declaration' supra fn 46 at 146: 'This difference in declaration language would seem to be without significance regarding the effect of the declaration'; but see Bailey 'Facing the Truth' supra fn 25 at 312. 99 McRae, DM (1978) 'The Legal Effect of Interpretative Declarations' (49) British Yearbook of International Law 155. 
trade that Article 90 CISG had specifically been drafted to cover. ${ }^{100}$ A possible reason might have been that Professor Gyula Eörsi, who had acted as a member of the Hungarian delegation to the Vienna Diplomatic Conference and, enjoying an excellent reputation and high respect within the international academic community, had also served as the President of the Conference, had written in a 1983 article that 'the trade law among COMECON countries inter se is unified and will remain unaffected by virtue of Art. 94 of the Convention'. ${ }^{101}$ This may have alerted Hungarian officials to the fact that the most prominent Hungarian expert on the CISG apparently did not concur with the view that saw the GDC CMEA covered by Article 90 CISG.

The interpretation of Article 90 CISG favoured by Hungary in its interpretative declaration turned out to be in conformity with the view adopted by the majority of international commentators ${ }^{102}$ and by a number of arbitral tribunals, which considered the (closely related) General Principles of Deliveries between the Soviet Union and the Peoples' Republic of China to be subject to Article 90 CISG. ${ }^{103}$ As far as can be ascertained, no Hungarian court ever addressed the applicability of Article 90 CISG to the GDC CMEA, nor is there any indication that courts in other countries have taken note of Hungary's interpretative declaration.

100 See Schroeter UN-Kaufrecht und Europäisches Gemeinschaftsrecht supra fn 8 at $\S 9$ paras 12 et seq (with extensive references to Article 90 CISG's legislative history).

101 Eörsi, G (1983) 'A Propos the 1980 Vienna Convention on Contracts for the International Sale of Goods' (31) American Journal of Comparative Law 333 at 342.

102 See Enderlein and Maskow International Sales Law supra fn 9 at Art 90 no 2; Heuzé, V (2000) La vente internationale de marchandises: Droit uniforme L.G.D.J. no 112; Kritzer Guide to Practical Applications supra fn 81 at 551; Magnus Kommentar supra fn 40 at Art 90 para 9.

103 Tribunal of International Commercial Arbitration at the Russian Federation Chamber of Commerce and Industry, 14 April 1998, No. 47/1997, available at: http:// www.cisg.law.pace.edu/cisg/wais/db/cases2/980414r1.html, para 3.1; Tribunal of International Commercial Arbitration at the Russian Federation Chamber of Commerce and Industry, 2 October 1998, No. 113/1997, available at: http://www.cisg.law.pace. edu/cisg/wais/db/cases2/981002r1.html, para 3.1; Tribunal of International Commercial Arbitration at the Russian Federation Chamber of Commerce and Industry, 22 March 2002, No. 225/2000, available at: http://www.cisg.law.pace.edu/cisg/wais/ $\mathrm{db} /$ cases2/020322r1.html, paras 1.2, 3.3. 
The German Declaration on Articles 1(1)(b) and 95 CISG

The Federal Republic of Germany made the following declaration when acceding to the Convention:

'The Government of the Federal Republic of Germany holds the view that Parties to the Convention that have made a declaration under article 95 of the Convention are not considered Contracting States within the meaning of subparagraph (b) of article 1 of the Convention. Accordingly, there is no obligation to apply - and the Federal Republic of Germany assumes no obligation to apply - this provision when the rules of private international law lead to the application of the law of a Party that has made a declaration to the effect that it will not be bound by subparagraph (1) (b) of article 1 of the Convention. Subject to this observation the Government of the Federal Republic of Germany makes no declaration under article 95 of the Convention.'

As is clear from its last sentence, the statement cited was neither meant to constitute a reservation in accordance with Article 95 CISG nor a 'partial' reservation, ${ }^{104}$ but an interpretative declaration. ${ }^{105}$ In its declaration, the Government of the Federal Republic of Germany 'interpreted' both Articles 1(1) (b) and 95 CISG in a particular manner and thus chose to take a position in a dispute which - as has been noted above - continues until today. In this context, it is not without interest to remember that the German delegation to the Vienna Diplomatic Conference had vigorously criticized both Articles 1(1) (b) and 95 CISG, but had eventually failed in its attempts to have the provisions removed from the Convention's text. ${ }^{106}$

104 But see Reinhart UN-Kaufrecht supra fn 11 at Art 2 VertragsG para 1; Lüderitz, A and Fenge, A in Soergel, HT (2000) Bürgerliches Gesetzbuch, Vol. 13: Schuldrechtliche Nebengesetze - CISG (13th ed) Kohlhammer at Art 1 para 16.

105 Ferrari in Schlechtriem \& Schwenzer Kommentar supra fn 78 at Art 1 para 79; Herber and Czerwenka Internationales Kaufrecht supra fn 9 at Art 1 para 19; Magnus Kommentar supra fn 40 at Art 1 para 112.

106 See Delegate Herber (Federal Republic of Germany) in Official Records supra fn 36 p 236-237. 


\section{Legal Significance of Interpretative Declarations}

The CISG's Final Provisions do not address interpretative declarations. Their legal significance is therefore subject to the applicable standards of public international law. ${ }^{107}$ Although a clear view or practice in this matter has not emerged, ${ }^{108}$ it is beyond dispute that an interpretative declaration may not be made where such a declaration is prohibited by the treaty it is relating to. This is precisely the situation under the CISG: While interpretative declarations are not contrary to Article $98 \mathrm{CISG},{ }^{109}$ it is submitted that they are incompatible with Article 7(1) CISG, ${ }^{110}$ as this provision declares an internationally uniform interpretation to be the CISG's decisive goal and, even more important, delegates the task of developing the Convention's interpretation to the courts and not the government or parliament of the individual Contracting States. ${ }^{111}$ Article 7(1) CISG accordingly prohibits Contracting States from influencing the Convention's interpretation through interpretative declarations. Any interpretative declaration that is made nevertheless must therefore remain without legal effect. ${ }^{112}$

One might add that, under public international law, this result is not changed by the fact that the UN Secretary-General as the depositary of the Convention (Article 89 CISG) accepted the declarations by Hungary and Germany for deposit and communicated their text to all Contracting States: Article 77 Vienna Convention on the Law of Treaties ${ }^{113}$ makes it clear that the depositary's functions in this respect are limited to receiving those communications and informing other States thereof, without granting the deposi-

107 Schlechtriem in Schlechtriem \& Schwenzer Commentary supra fn 17 at Art 98 para 2.

108 McRae 'Interpretative Declarations' supra fn 99 at 160.

109 But see Bridge The International Sale of Goods supra fn 26 at para $2.44 \mathrm{fn}$ 171.

110 Ferrari 'Short notes' supra fn 64 at 251; Torsello 'Reservations' supra fn 21 at 117 (both on Germany's interpretative declaration).

111 See Basedow 'Uniform Private Law Conventions' supra fn 66 at 735: 'With the exception of reservations permitted in the convention, the binding treaty only leaves national legislators a choice between "yes" and "no".'

112 See Torsello 'Reservations' supra fn 21 at 117.

113 Article 77 Vienna Convention on the Law of Treaties governs the depositary's functions under the CISG; see Schlechtriem in Schlechtriem \& Schwenzer Commentary supra fn 17 at Art 89 para 2. 
tary any power to adjudicate on the declaration's validity or its legal effect. ${ }^{114}$ In addition, the fact that all other Contracting States remained silent in the face of the Hungarian and the German interpretative declarations is similarly without relevance: Article 20(5) Convention on the Law of Treaties is inapplicable as it is only concerned with reservations, and there is no duty to respond to interpretative declarations under general international law. ${ }^{115}$ Inaction can accordingly not be treated as aquiescence, and does not cure the declarations' legal insignificance.

\section{Interpretative Declarations and Interpretative Domestic Legislation}

Finally, some Contracting States have enacted domestic laws which purport to interpret certain provisions of the CISG. Legislation of this kind can eg be found in Canada, ${ }^{116}$ Germany ${ }^{117}$ and Norway. ${ }^{118}$ Unlike the 'interpretative declarations' discussed above, these cases of interpretative domestic legislation have not been communicated to the depositary of the Convention, and their content has therefore not even been brought to the other Contracting States' attention. According to the applicable rules of public international law, interpretative domestic legislation is of no legal significance to other Contracting States and their courts, which are therefore not only entitled to disregard its content, but are even obliged to do so because of their obligation to apply the Convention's rules in accordance with Article 7(1) CISG. ${ }^{119}$

As Article 7(1) CISG has to be observed by every Contracting State, those Contracting States which have prescribed a certain interpretation by way of an interpretative domestic legislation are arguably acting in violation of public international law. This is certainly the case if the content of the interpretative domestic legislation departs from the prevailing international

\footnotetext{
114 McRae 'Interpretative Declarations' supra fn 99 at 171.

115 McRae 'Interpretative Declarations' supra fn 99 at 169.

116 Most Canadian provinces have enacted laws interpreting Article 6 CISG; see Ziegel, J (1991) 'Canada Prepares to Adopt the International Sales Convention' (18) Canadian Business Law Journal 1 at 3.

117 Article 2 of the German Vertragsgesetz, which repeats the content of Germany's 'interpretative declaration' pertaining to Articles 1(1)(b) and 95 CISG (see above).

118 See Hagstrøm, V (2006) 'CISG - Implementation in Norway, an approach not advisable' Internationales Handelsrecht 246 at 247-248.

119 See Ziegel 'Canada Prepares to Adopt' supra fn 116 at 11.
} 
interpretation of the CISG provisions concerned, given that Article $27 \mathrm{Vi}$ enna Convention on the Law of Treaties explictly provides that '[a] party may not invoke the provisions of its internal law as justification for its failure to perform a treaty'. ${ }^{120}$ But Article 7(1) CISG, it is submitted, should be read as going even further: Any domestic act which requires courts to follow a national legislator's view when interpreting the Convention should be regarded as a violation of the Contracting State's obligations arising from the Convention, even if the CISG's interpretation laid down in the interpretative domestic legislation should be in accordance with the internationally prevailing view. ${ }^{121}$

\section{SUCCESSION OF STATES AND THE CISG}

The Succession of States ${ }^{122}$ is a phenomenon that has gained some importance for the Convention's applicability, in particular through its impact upon certain territories' status as 'Contracting States' under the CISG. Since the CISG's Final Provisions provide no specific rules addressing these developments, recourse has to be had to rules of customary public international law. The definition of those rules is, however, unfortunately difficult, ${ }^{123}$ as only some of the provisions in the Vienna Convention on Succession of States in

\footnotetext{
120 This raises the following question: Are the courts in States which have enacted an interpretative domestic legislation free to depart from the domestic law in favour of an international interpretative approach? The matter has to be decided in accordance with the respective constitutional law, and cannot be discussed here. Suffice it to say that at least one commentator has argued that German courts are not bound by domestic interpretative law in this situation, but should follow Article 7(1) CISG; see Magnus Kommentar supra fn 40 at Art 1 para 111.

121 Cf Hagstrøm 'CISG - Implementation in Norway' supra fn 118 at 247.

122 See Brownlie, I (1998) Principles of Public International Law (5th ed) Oxford University Press at p 650: 'It is of great importance to note that the phrase "state succession" is employed to describe an area, or a source of problems: the term does not connote any principle or presumption that a transmission or succession of legal rights and duties occurs.'

123 Cf Aust Modern Treaty Law supra fn 19 at p 307: 'It is [...] a particularly uncertain and controversial area of international law'; Brownlie Principles of Public International Law supra fn 122 at p 650; Gamarra, Y (2000) 'Current Questions of State Succession Relating to Multilateral Treaties' in Eisemann, PM and Koskenniemi, M (eds) State Succession: Codification Tested against the Facts Martinus Nijhoff p 387 at 388 .
} 
respect of Treaties of 23 August 1978 are regarded as codifying customary international law. ${ }^{124}$

\section{Uniform Law in a World of Shifting Borders}

Soon after the CISG had entered into force on 1 January 1988, the world entered a new era that was marked by significant changes on the global political landscape: Within a couple of years, a number of States that had participated in the Vienna Diplomatic Conference of 1980 and had subsequently ratified the Sales Convention would cease to exist, new States would be established in their place and again others would encounter changes in their borders.

The first change in the fledgling CISG landscape was caused by the German reunification on 3 October 1990, when the German Democratic Republic (then already a CISG Contracting State) acceeded to the Federal Republic of Germany (at that stage still a non-Contracting State). ${ }^{125}$ In 1991, the Union of Soviet Socialist Republics (USSR) - for which the CISG entered into force on 1 September that year - began to dissolve, and a significant number of independent States emerged, which among them adopted a variety of positions towards the Convention (see below). The Socialist Federal Republic of Yugoslavia, which had been a CISG Contracting State since 1 January 1988, similarly underwent significant changes, when from 1991 onwards most of its republics declared their independence.

Effective 1 January 1993, another Contracting State - the Czechoslovak Socialist Republic (CSSR) ${ }^{126}$ - dissolved and left the Czech Republic and the Slovak Republic as its successors. On 1 July 1997, the territory of Hong

124 See Aust Modern Treaty Law supra fn 19 at p 306; Gamarra 'Current Questions' supra fn 123 at 434; Williams, PR (1994) 'The Treaty Obligations of the Successor States of the former Soviet Union, Yugoslavia and Czechoslovakia: Do They Continue in Force?' (23) Denver Journal of International Law and Policy 1 at 8. The practice of the Secretary-General of the United Nations, however, is based on the assumption that the Vienna Convention essentially codifies customary international law; cf Zimmermann, A (2000) Staatennachfolge in völkerrechtliche Verträge Springer at $\mathrm{p}$ 755-757.

125 The CISG entered into force for the Federal Republic of Germany on 1 January 1991.

126 The CISG had entered into force for the CSSR on 1 April 1991. 
Kong - which since 1842 had been a British crown colony, and therefore part of a Non-Contracting State - was restored to the People's Republic of China (a CISG Contracting State), and on 20 December 1999 a similar development finally took place with respect to Macao, which for centuries had been administered by Portugal (another non-Contracting State). ${ }^{127}$

\section{Effect of State successions upon the Status as a CISG 'Contracting State'}

In determining the legal effect that a State succession (as the ones described above) may have upon the affected territories' status as a CISG 'Contracting State', a number of different scenarios need to be distinguished:

\section{Dissolution and Separation of States}

When a part or parts of the territory of a Contracting State for which the CISG is in force separate to form one or more States (as in case of the USSR, the former Yugoslavia and the CSSR), two possible, but mutually exclusive principles may apply: According to the 'continuity principle', the Convention would automatically continue in force in respect of each successor State so formed. Articles 34(1)(a), 35 Vienna Convention on Succession of States in respect of Treaties are based on the assumption that this 'continuity principle' constitutes the general rule. According to the 'clean-slate principle', on the contrary, the Convention ratified by the predecessor State would only become binding upon the successor State once the latter has filed a formal notification of succession. Although this approach has been codified in Articles 17-23 Vienna Convention on Succession of States in respect of Treaties for 'newly independent States' (ie former colonies and dependent territories ${ }^{128}$ ) only, it is widely assumed that the 'clean-slate principle' also applies to certain other cases, ${ }^{129}$ in particular to States which came into existence through

\footnotetext{
127 See Schroeter 'The Status of Hong Kong and Macao' supra fn 15 at 312.

128 See the definition of 'newly independent States' in Article 2(1)(f) Vienna Convention on Succession of States in respect of Treaties.

129 Brownlie Principles of Public International Law supra fn 122 at p 663-664; Gamarra 'Current Questions' supra fn 123 at 393; Zimmermann Staatennachfolge supra fn 124 at p 826.
} 
separation from a predecessor State which continues to exist ('separation' or 'cession' as opposed to complete 'dismembration' or 'dissolution'). ${ }^{130}$ When applied to rights and obligations arising from the CISG, the principles just mentioned lead to the following results:

No practical difficulties arise whenever a successor State's status as a Contracting State is being supported through a notification of succession which the successor State files with the treaty's depositary. With respect to the CISG, this step was taken by the Russian Federation (successor to the USSR, and continuing its international legal personality), Belarus (successor to the Byelorussian SSR), the Ukraine (successor to the Ukrainian SSR), the Czech Republic and the Slovak Republic (successors to the CSSR), Bosnia and Herzegovina, Croatia, Slovenia, and Macedonia (adopting the name 'The former Yugoslav Republic of Macedonia') (successors to the Socialist Federal Republic of Yugoslavia, the so-called 'former Yugoslavia'), as well as the Republic of Serbia and the Republic of Montenegro (successors to Serbia and Montenegro, a State which - under the then name of 'Federal Republic of Yugoslavia' - had also been a successor to the 'former Yugoslavia $\left.{ }^{131}\right)$. While the legal certainty created by the notification procedure is only too welcome, it is worth remembering that, from a dogmatic point of view, the Contracting State status of the above mentioned States arguably arose ipso iure because of the 'continuity principle': Their notifications of succession were therefore purely declaratory in nature, ${ }^{132}$ merely confirming a situation which, by international law, already existed. ${ }^{133}$

130 Shaw, MN (2003) International Law (5th ed) Cambridge University Press at p 879; Zimmermann Staatennachfolge supra fn 124 at p 826; but see Brownlie Principles of Public International Law supra fn 122 at p 663 who even states that the 'clean slate principle' constitutes the general rule.

131 The Federal Republic of Yugoslavia had been created in 1992 and claimed to continue the international legal personality of the former Yugoslavia, to which the former republics now independent - see above - objected.

132 Note that, according to Article 9 Vienna Convention on Succession of States in respect of Treaties, a unilateral notification of succession by a successor State alone does not suffice in order to transfer the rights and duties under a treaty.

133 A difference between a notification of succession establishing the Contracting State status and a notification (unnecessarily) conforming it would only arise as far as the period between the date of succession and the notification of succession is concerned: However, this difference is being removed whenever a notification of succession declares the Convention retroactively applicable. 
Another group of successor States refrained from filing a notice of succession, and instead selected to ratify the CISG themselves. This approach was adopted by a significant number of States whose territories previously formed part of the USSR, namely Estonia, Georgia, Kyrgyzstan, Latvia, Lithuania, Moldova and Uzbekistan. ${ }^{134}$ It is in accordance with what seems to be the prevailing view with respect to the legal situation of the former Soviet republics, which - apart from the Russian Federation, which continued the USSR (Article 35 Vienna Convention on Succession of States in respect of Treaties) - are considered to have inhereted a 'clean slate'. ${ }^{135}$ Their position as a CISG Contracting State was therefore established by acceding to the Convention de novo in their own name.

Finally, a number of States whose territory previously formed part of the USSR - Armenia, Azerbaijan, Kazakhstan, Tjikistan and Turkmenistan ${ }^{136}-$ neither deposited an instrument of accession with the depositary of the CISG in accordance with Article 91(3), (4) CISG, nor made a notification of succession establishing their succession to the USSR's rights and obligations arising from the CISG. These former Soviet republics - who, in short, simply remained silent - can therefore currently not be considered 'Contracting States' under the CISG, as the 'clean slate principle' governing their position removed the legal nexus between the Convention and their respective territories. ${ }^{137}$

\section{Territory of a State Becoming Part of Another State}

A somewhat different development takes place when a certain territory (within which sellers or buyers may reside) and which, under public inter-

134 As mentioned above, Armenia also filed an instrument of accession in 2006, but apparently withdrew it.

135 Brownlie Principles of Public International Law supra fn 122 at p 664; Gamarra 'Current Questions' supra fn 123 at 419; Korman, ST (1992) 'The 1978 Vienna Convention on Succession of States in respect of Treaties: An Inadequate Response to Issues of State Succession' (16) Suffolk Transnational Law Review 174 at 188-189 (on the Baltic States).

136 For background information on these countries' position towards the CISG, see Knieper, R (2005) 'Celebrating Success by Accession to CISG' (25) Journal of Law and Commerce 477, at 479-480.

137 See supra fn 135. 
national law, is (part of) one State, now becomes part of another (already existing) State. A change of this kind can affect the applicability of the CISG in two different constellations, both of which have already occurred in the history of the Convention:

The first development to be considered involves a Contracting State (or part thereof) becoming part of a Non-Contracting State. This happened when the German Democratic Republic, which had been a CISG Contracting State since 1 March 1990, effective 3 October 1990 acceded to the Federal Republic of Germany (at that time still a Non-Contracting State, as the Convention only entered into force for the Federal Republic of Germany on 1 January 1991). Generally speaking, upon becoming part of the territory of another State, treaties of the predecessor State cease to be in force in respect of the territory to which the succession of States relates, as provided by Article 15(a) Vienna Convention on Succession of States in respect of Treaties. As the German reunification was marked by a number of unique circumstances, ${ }^{138}$ commentators are divided if this solution also applies to Eastern Germany's status under the CISG between 3 October 1990 and 1 January $1991 .{ }^{139}$ Suffice it to say that the point has not gained any practical relevance, as no international sales contract concluded by an Eastern German party during this brief period has been reported that would have raised the question of the Convention's applicability.

The reverse situation occured when on 1 July 1997 the territory of Hong Kong - which was at that point a British crown colony, and therefore part of a CISG non-Contracting State - was restored to the People's Republic of China (a CISG Contracting State), and when on 20 December 1999 a similar development took place with respect to Macao, which for centuries had been administered by Portugal (another non-Contracting State). As I have argued in more detail elsewhere, ${ }^{140}$ the transfer of Hong Kong and Macao to the People's Republic of China resulted in those two territories becom-

138 See Gamarra 'Current Questions' supra fn 123 at 402 et seq.

139 See Magnus Kommentar supra fn 40 at Einl zum CISG paras 15-17 (listing numerous references).

140 Schroeter 'The Status of Hong Kong and Macao' supra fn 15 at 320-326; Schroeter, UG (2004) 'Die Vertragsstaateneigenschaft Hongkongs und Macaus unter dem UN-Kaufrecht' Internationales Handelsrecht 7. 
ing part of a Contracting State from the date of the respective 'handover', ${ }^{141}$ an assessment which is in conformity with the 'moving-boundary principle' recognized as customary international law ${ }^{142}$ as well as the fact that China has not made a declaration under Article 93 CISG, by way of which it could have easily exempted its new 'Special Administrative Regions' from the territorial scope of the Convention. Courts ${ }^{143}$ as well as commentators ${ }^{144}$ have since adopted the position advocated here.

\section{Successions and Reservations}

Neither the Final Provisions of the CISG nor the Vienna Convention on Succession of States in respect of Treaties contain a specific provision which governs the legal destiny of reservations declared by a predecessor State. Under the CISG, this question has arisen with respect to the CSSR's reservation under Article 95 CISG, which was neither confirmed nor withdrawn in the notifications of succession filed by the Czech Republic and the Slovak Republic. ${ }^{145}$ Article 20(1) Vienna Convention on Succession of States in respect of Treaties (the scope of which is limited to newly independent States)

\footnotetext{
141 For Hong Kong: 1 July 1997; for Macao: 20 December 1999.

142 Cf Aust Modern Treaty Law supra fn 19 at p 307.
}

143 Oberlandesgericht Hamm (Germany), 12 November 2001, OLG-Report Hamm (2002), 185, available at: http://cisgw3.law.pace.edu/cases/011112g1.html: Convention applied to contract between a German buyer and a seller from Hong Kong according to Article 1(1)(a) CISG, as '[b]oth Germany and China are Contracting States to the CISG [and] the parties have their places of business in the States mentioned above'; Rechtbank van Koophandel Turnhout (Belgium), 18 January 2001 (Index Syndicate Ltd. v. NV Carta Mundi), available at: http://cisgw3.law.pace.edu/ cases/010118b1.html: 'both Belgium and the People's Republic of China, of which Hong Kong again forms part, have ratified the Convention.'

144 Magnus Kommentar supra fn 40 at p 30; McNamara, T (2003) 'U.N. Sale of Goods Convention: Finally Coming of Age?' (32) Colorado Lawyer 11 at 13; Posch, W in Schwimann, M (ed) (2006) ABGB Praxiskommentar, Vol 4 (3rd ed) LexisNexis at Art 93 para 4; Schlechtriem in Schlechtriem \& Schwenzer Commentary supra fn 17 at Art 1 para 9; Shen, J (1998) 'Cross-Strait Trade and Investment and the Role of Hong Kong' (16) Wisconsin International Law Journal 661 at 668; but see Buschbaum, M (2004) 'Anwendbarkeit des UN-Kaufrechts im Verhältnis zu Hongkong' Praxis des Internationalen Privat- und Verfahrensrechts 546.

145 Cf De Ly 'Sources' supra fn 77 at 10: 'There is some doubt whether the Czechoslovakian reservation survived that country's split.' 
provides that the successor State shall be considered as maintaining any reservation which was applicable at the date of the succession of States, unless it expressly states otherwise. Although Articles 30-38 Vienna Convention lack a similar provision, it is submitted that the same must apply to other cases of State succession, as the 'continuity principle' is based on the very idea that the predecessor's scope of treaty obligations survives the succession unchanged. ${ }^{146}$ As a result, the reservation according to Article 95 CISG is still effective for the Czech and the Slovac Republic. ${ }^{147}$

\section{THE CONVENTION'S RELATIONSHIP WITH OTHER INTERNATIONAL INSTRUMENTS: ARTICLES 90, 94 CISG AND EUROPEAN COMMUNITY LAW}

A most difficult question relating to the position of the CISG within the international legal order is raised by the developing 'regionalisation' of international business law: ${ }^{148}$ Which rules should govern the relationship between the Convention on one hand and instruments adopted by regional communities of States on the other hand in case these instruments apply to international contracts subject to the CISG, but provide for solutions that differ from those used in the Convention? Such a 'conflict of norms' between two international instruments is currently most likely to occur between the CISG and instruments adopted by the European Community, as the vast majority of its Member States have also ratified the CISG. The European Community legislation in force already contains a number of provisions not in harmony with the Convention, amongst others in the Consumer Sales Directive, ${ }^{149}$

146 Zimmermann Staatennachfolge supra fn 124 at p 755-757. But see Brownlie Principles of Public International Law supra fn 122 at p 668, who characterizes the issue as 'yet unsettled'.

147 Magnus Kommentar supra fn 40 at Art 95 para 4; Schlechtriem in Schlechtriem \& Schwenzer Commentary supra fn 17 at Art 1 para 41; but see Enderlein, F (1997) 'Vienna Convention and Eastern European Lawyers' IBA International Sales Quarterly 12 .

148 De Ly 'Sources' supra fn 77 at 3; see Schroeter UN-Kaufrecht und Europäisches Gemeinschaftsrecht supra fn 8 at $\S \S 6-15$.

149 Directive 1999/44/EC of the European Parliament and of the Council of 25 May 1999 on certain aspects of the sale of consumer goods and associated guarantees; see Schroeter UN-Kaufrecht und Europäisches Gemeinschaftsrecht supra fn 8 at $\S 6$ paras 188-290, § 15 paras 89-120. 
the Distance Selling Directive, ${ }^{150}$ the Directive on Late Payments ${ }^{151}$ and the Brussels Regulation. ${ }^{152}$ In the future, comparable conflicts also seem possible between the Convention and Actes Uniformes adopted by the Organisation for the Harmonisation of Business Law in Africa (better known under its French acronym 'OHADA') ${ }^{153}$ or Decisiones adopted by the Mercado Comun del Sur (MERCOSUR). ${ }^{154}$

The CISG's Part IV contains two provisions designed to govern the Convention's relationship with concurrent international instruments ('Relationsnormen ${ }^{155}$ ), namely Article 90 CISG and Article 94 CISG. They differ both in their scope of application and in their legal effect: While Article 90 CISG merely applies to 'international agreements' concluded by Contracting States, but accords prevalence to any of those agreements without requiring any specific action by a State involved, Article 94 CISG accommodates any instrument that introduces the same or closely related legal rules into the participating States' legal systems, but does require explicit declarations of

150 Directive 97/7/EC of the European Parliament and of the Council of 20 May 1997 on the protection of consumers in respect of distance contracts; see Schroeter $U N$-Kaufrecht und Europäisches Gemeinschaftsrecht supra fn 8 at $\S 6$ paras 126-187, $\S 15$ paras $76-88$.

151 Directive 2000/35/EC of the European Parliament and of the Council of 29 June 2000 on combating late payment in commercial transactions; see Schroeter $U N$ Kaufrecht und Europäisches Gemeinschaftsrecht supra fn 8 at $\S 6$ paras 337-399, $\S 15$ paras 121-166.

152 Council Regulation (EC) No 44/2001 of 22 December 2000 on jurisdiction and the recognition and enforcement of judgments in civil and commercial matters; see Schroeter UN-Kaufrecht und Europäisches Gemeinschaftsrecht supra fn 8 at $\S 6$ paras $16-34, \S 15$ paras $7-23$.

153 While the Acte uniforme sur le droit commercial général the OHADA adopted on 17 April 1997 is largely based on the CISG, it does contain a number of potentially conflicting provisions; see Schroeter, UG (2001) 'Das einheitliche Kaufrecht der OHADA-Staaten' Law in Africa 163 at 167. That a conflict with the CISG must currently seem unlikely is due to the fact that among the OHADA States only Gabon and Guinea have adopted the Convention.

154 On conflicts between such acts and international conventions in general see Basedow, J (2003) 'Worldwide Harmonisation of Private Law and Regional Economic Integration - General Report' Uniform Law Review 31 at 38; specifically on conflicts with the CISG see Schroeter UN-Kaufrecht und Europäisches Gemeinschaftsrecht supra fn 8 at $\S 9$ para 41.

155 On this German legal term, see Schroeter UN-Kaufrecht und Europäisches Gemeinschaftsrecht supra fn 8 at $\S 7$ paras 27-30. 
non-application to be made to the depositary in order discard the CISG's applicability in favor of these unified or harmonised legal rules.

Although the applicability of Articles 90 and 94 CISG to secondary European Community law is still hotly disputed, it is submitted that Article 90 CISG can neither be applied to EC regulations nor EC directives, ${ }^{156}$ as these acts do not qualify as 'international agreements' and have - maybe more importantly - not been entered into by Contracting States to the CISG (as required by Article 90 CISG), but rather enacted by the European Community, a legal entity not party to the Convention. ${ }^{157}$ Secondary European Community law could therefore only displace the CISG by way of Article 94 CISG (as EC regulations introduce the 'same' and EC directives - at least in most cases - 'closely related legal rules'), ${ }^{158}$ but would require the necessary reservations to be expressly declared (Article 97(2) CISG). The latter requirement will contribute to legal certainty, ${ }^{159}$ and may even lead the EC Member States to reconsider the desirability of discarding the existing global uniform law in favor of a merely regional harmonisation of laws.

156 Ferrari, F (2003) 'Universal and Regional Sales Law: Can They Coexist?' Uniform Law Review 177 at 182; Janssen, A (2003) 'The final seller's right of redress under the Consumer Sales Directive and its complex relationship with the CISG' European Legal Forum 181 at 183; Magnus Kommentar supra fn 40 at Art 90 paras 4, 10; Schlechtriem in Schlechtriem \& Schwenzer Commentary supra fn 17 at Art 90 paras 12-13; Schroeter UN-Kaufrecht und Europäisches Gemeinschaftsrecht supra fn 8 at $\S 9$ para 45. Contra Herber, R in Schlechtriem, P (ed) (1998) Commentary on the UN Convention on the International Sale of Goods Oxford University Press at Art 94 para 3; Herber and Czerwenka Internationales Kaufrecht supra fn 9 at Art 90 para 4; Siehr, K in Honsell, H (ed) (1997) Kommentar zum UN-Kaufrecht Springer at Art 90 para 7; Witz in Witz, Salger \& Lorenz International Einheitliches Kaufrecht supra fn 11 at Art 90 para 3.

157 See in more detail Schroeter UN-Kaufrecht und Europäisches Gemeinschaftsrecht supra fn 8 at $\S 9$ paras 33-40.

158 Janssen 'The final seller's right of redress' supra fn 156 at 183-184; Magnus Kommentar supra fn 40 at Art 94 para 1; Schroeter UN-Kaufrecht und Europäisches Gemeinschaftsrecht supra fn 8 at $\S 10$ para 11. Contra Ernst, B (2002) Das Wiener Übereinkommen von 1980 über Verträge über den internationalen Warenkauf (UN-Kaufrecht) im Recht der Produkthaftung Shaker 98; Ferrari in Schlechtriem \& Schwenzer Kommentar supra fn 78 at Art 94 para 5.

159 Schlechtriem in Schlechtriem \& Schwenzer Commentary supra fn 17 at Art 94 para 3; but see Torsello 'Reservations' supra fn 21 at 95 (who reaches the opposite conclusion). 
At the time of writing, no declaration under Article 94 CISG in favor of European Community law has been made, and the prevalence of the Convention accordingly stands. ${ }^{160}$

\section{FUTURE ACCESSIONS: THE LIMITATION TO 'STATES' (ARTICLE 91(3) CISG)}

When thinking about the future of the Convention, one might contemplate a future accession not only by other States, but also by regional or international organisations. Such a step, which has already been advocated by commentators with a view to a possible accession of the European Community to the CISG, ${ }^{161}$ raises the interesting question if the Final Provisions of the CISG allow for the membership of an international entity as the European Community or, for example, the OHADA.

The relevant provision is Article 91(3) CISG, which provides that the Convention 'is open for accession by all States which are not signatory States as from the date it is open for signature'. This so-called 'all-states clause' is in accordance with Article 6 of the Vienna Convention on the Law of Treaties, which addresses the related issue of each State's capacity to conclude treaties. At the time of its adoption in 1980, Article 91(3) CISG was considered a liberal clause, as comparable provisions in older conventions had often stated that only Member States of the UN or of one of its special agencies could become Contracting States, ${ }^{162}$ thereby excluding accession by States that were not internationally recognized and, for that matter, by international organizations.

The wording of Article 91(3) CISG as it stands, however, still only provides for an accession of 'States' to the Convention. The European Com-

\footnotetext{
160 Cf also Article 307(2) EC Treaty.

161 Basedow, J (2003) 'Die Europäische Gemeinschaft als Partei von Übereinkommen des einheitlichen Privatrechts' in Schwenzer, I and Hager, G (eds) Festschrift für Peter Schlechtriem zum 70. Geburtstag Mohr Siebeck 165; Hartley, T (1979) The Law relating to the International Sale of Goods Commission of the European Communities para 1.30; Schwartze, A (2000) Europäische Sachmängelgewährleistung beim Warenkauf Mohr Siebeck 597 (for an accession of the European Union).

162 Schlechtriem in Schlechtriem \& Schwenzer Commentary supra fn 17 at Art 91 para 2 fn 2.
} 
munity, on the other hand, clearly does not constitute a State in the sense employed by public international law, which, according to some authors, suffices to effectively bar an accession of the European Community. ${ }^{163}$ The better reasons, it is submitted, militate in favor of a more flexible interpretation of Article 91(3) CISG, which would also be in accordance with the practice that has developed in the application of this treaty provision (cf Article 31(3)(b) Vienna Convention on the Law of Treaties): The fact that the USSR became a Contracting State at a time when the Byelorussian SSR and the Ukrainian SSR - which formed part of the USSR, but had both not been recognized as sovereign by most States ${ }^{164}$ - were already Contracting States to the CISG in their own right, aptly demonstrates that political factors have always played a significant role within the interpretation of Article 91(3) CISG. The wording of this final provision thus does not necessarily prevent an accession by the European Community. ${ }^{165}$

More important problems are raised by the application of Article 1(1)(a) CISG in constellations involving international organizations: As this central provision requires the parties to have their places of business in different Contracting States, the legal status of the European Community as one Contracting State would result in all intra-Community contracts failing to fulfill the requirements of Article 1(1)(a) CISG - all EU companies would suddenly be based within one and the same Contracting State. ${ }^{166}$ The application of Article 1(1)(a) CISG to international organizations comprising several States which, in their own right, also qualify as Contracting States under the Convention, does therefore not correspond to the CISG's sphere of applicability, and would create significant legal uncertainty. It is submitted that the reason

163 Basedow 'Die Europäische Gemeinschaft als Partei von Übereinkommen' supra fn 161 at 180-181; Tilmann, W (1993) 'Eine Privatrechtskodifikation für die Europäische Gemeinschaft?' in Müller-Graff, P-C (ed) Gemeinsames Privatrecht in der Europäischen Gemeinschaft Nomos 485 at 488.

164 Aust Modern Treaty Law supra fn 19 at p 312.

165 Schroeter UN-Kaufrecht und Europäisches Gemeinschaftsrecht supra fn 8 at $\S 19$ para 41 .

166 See Secretariat's Commentary in Official Records supra fn 36 p 14 at Art 1 no 3: 'This Convention is not concerned with the law governing contracts of sale or their formation where the parties have their places of business within one and the same State.' 
why the European Community cannot acceed to the CISG accordingly lies in the Convention's Part I (namely Article 1(1) CISG), not its Part IV..$^{167}$

\section{CONCLUSION}

The present article has tried to demonstrate that the CISG's 'Final Provisions', although routinely neglected by commentators, often play an important role in the Convention's application. The existing case law on Articles 89-101 CISG shows that courts and arbitral tribunals have generally been able to handle the difficulties that the interpretation of 'Part IV' occasionally presents, and that - with one notable exception ${ }^{168}$ - the goal of an internationally uniform interpretation (Article 7(1) CISG) has largely been achieved. Apart from the role they play within the CISG's everyday application, the Convention's 'Final Provisions' have yet a different purpose to fulfil: They provide the framework that will determine if the Convention, as it is growing older, has the necessary flexibility to adapt to the legal and political changes that the future may hold. Insofar, Part IV may indeed be described as the Convention's 'backbone': Like every backbone, it sustains and gives firmness to the entire body (of the CISG), and as long as it is being treated with care, one might almost be tempted to forget it exists.

167 Schroeter UN-Kaufrecht und Europäisches Gemeinschaftsrecht supra fn 8 at $\S 19$ paras 44-47.

168 On the divergent case law on the effect of a reservation under Article 96 CISG, see supra $\mathrm{p}$ 441-444. 